\title{
R. Revista

\section{Termite Mounds Effects on Soil Properties in the Atlantic Forest Biome}

\author{
Sandra Santana de Lima ${ }^{(1)}$, Marcos Gervasio Pereira ${ }^{(2)^{*}}$, Renato Nunes Pereira ${ }^{(3)}$, \\ Rafael Moura de Pontes ${ }^{(4)}$ and Celeste Queiroz Rossi ${ }^{(1)}$ \\ (1) Universidade Federal Rural do Rio de Janeiro, Instituto de Agronomia, Departamento de Solos, Programa \\ de Pós-Graduação em Ciência do Solo, Seropédica, Rio de Janeiro, Brasil. \\ (2) Universidade Federal Rural do Rio de Janeiro, Instituto de Agronomia, Departamento de Ciência do Solo, \\ Seropédica, Rio de Janeiro, Brasil. \\ (3) Universidade Federal Rural do Rio de Janeiro, Departamento de Matemática, Seropédica, Rio de Janeiro, Brasil. \\ (4) Universidade Federal Rural do Rio de Janeiro, Departamento de Engenharia, Graduação em Engenharia \\ Agrícola e Ambiental, Seropédica, Rio de Janeiro, Brasil.
}

\begin{abstract}
Termites have peculiar activities in the soil, inducing significant changes in the soil properties. The objective of this study was to assess physical and chemical properties and soil organic matter to evaluate the effect of termite activity and termite mounds on the soil. Two toposequences were selected and divided in slope thirds (shoulder, backslope, and footslope). In each of these, four termite mounds were selected. Samples were taken from the soils and termite mounds (top, center, and base) along with a variety of termites for identification. Analyses were carried out for physical, soil texture, and chemical properties, as well as for particle size and chemical fractioning of organic matter. The species Cornitermes cumulans was found in all mounds. Soil with termite mound presented higher clay content, acidity, and $\mathrm{Al}^{3+}$ content. Phosphorus contents differed considerably between mound material and soil. Sum of bases and cation exchange capacity of the soil were higher in mounds, and differed within the mounds, according to the sampling height. Total organic carbon and particulate carbon content were highest at the mound base. A marked disparity was observed between the contents of humic substances in the mounds and surrounding soil, with humin fraction differences in distinct topographic position. The high nutrient contents detected in the termite mounds confirm the importance of termites in concentrating nutrients.
\end{abstract}

Keywords: Isoptera, termitaria, macronutrients, organic matter.
Copyright: This is an open-access article distributed under the terms of the Creative Commons Attribution License, which permits unrestricted use, distribution, and reproduction in any medium, provided that the original author and source are credited.
* Corresponding author:

Received: December 23, 2016

How to cite: Lima SS, Pereira MG, Pereira RN, Pontes RM, Rossi CQ. Termite mounds effects
soil properties in the Atlantic Forest biome. Rev Bras Cienc Solo. 2018;42:e0160564.

https://doi.org/10.1590/18069657rbcs20160564 


\section{INTRODUCTION}

The soil is the habitat of a wide diversity of invertebrate organisms, among these some specific groups induce changes that contribute to a wide range of essential benefits for the sustainability of natural and managed ecosystems (Barrios, 2007). At larger scales, ecosystem services are delivered through the functioning of self-organized inter-nested systems (Lavelle et al., 2016). Representatives of the invertebrate macrofauna such as termites, ants, and worms, the so-called "soil engineers" (Jones et al., 1997; Jouquet et al., 2006, 2014; Bottinelli et al., 2015), are the most comprehensively studied, due to their dominant abundance and biomass in temperate and tropical soils (Jouquet et al., 2014). These species can have major impact on soil dynamics and ecosystem functioning through their biogenic structures that can alter soil physical properties, create niche opportunities for a variety of organisms, and control their activities through physical and biochemical processes (Jouquet et al., 2015; Lavelle et al., 2016).

Termites play an important ecological role in many ecosystems, particularly in nutrient-poor environments (Avitabile et al., 2015). Therefore, they have been addressed in studies in different parts of the world, considering the impact of their activities on the soil, as well as their constructions. At the landscape scale, termite activities play a key role in the distribution of resources (Jouquet et al., 2004) through physical changes in biotic or abiotic materials (Ferreira et al., 2011). On a smaller scale, especially in the tropical savanna, termites are known to significantly influence soil properties (Rückamp et al., 2012) with the construction of their nests (termite mounds) (Fall et al., 2001). Furthermore, termites are known to influence the soil physical, chemical, and biological properties, water dynamics (Jouquet et al., 2016) and decomposition of organic matter, accelerating recycling by the facilitation of microbial activity (Jouquet et al., 2006).

Although tropical termites are able to live in either wood or soil, most of them are found in the soil, mainly in dry areas (Echezona and Igwe, 2012), and are fundamental for tropical ecosystems (Hausberger and Korb, 2016). These invertebrates promote bioturbation, a largely physical process that mainly involves changes in soil texture but can also affect other soil properties (Obi and Ogunkunle, 2009). In addition, different kinds of termites may have strongly divergent effects on the availability of soil nutrients and the vegetation growing on these soils, as a result of differences in the structure and functioning of the mounds (Gosling et al., 2012).

Most of the termite mounds are sites of high nutrients contents. Redistribution of this material to the soil surface depends on soil erosion, translocation of nutrients from occupied and unoccupied mounds, and the nature of the species (Holt and Lepage, 2000; Rückamp et al., 2009). As long as intact, mounds often have a particularly dense waterproof surface (Jouquet et al., 2004). Different parts of the mounds usually have distinct ecological functions. The role of the outer wall is to protect the mounds from rain and predators, while the inner wall has a defense function and is mostly inhabited by soldier termites (Rückamp et al., 2010). Moreover, there are reports on a higher content of organic matter in the interior of the termite mounds than in the surrounding soils (Peres Filho et al., 1990; Holt and Lepage, 2000; Sarcinelli et al., 2009; Bezerra-Gusmão et al., 2011).

In Brazil, termite mounds are abundant, especially in areas converted to pasture (Rückamp et al., 2009). The presence of termites is commonly associated with soil degradation, declining fertility, and mainly increased soil acidity levels. However, in a study by Lima et al. (2011), none of the analyzed degradation indicators confirmed any relation between the amount of termite mounds and the degree of pasture degradation. Despite this progress in the knowledge of the abundance of species that build epigean mounds such as $C$. cumulans, little is known about the impact of termite activities on the ecosystem. Considering the hypothesis that termite mounds accumulate nutrients and can favor the surrounding area, this study assessed the physical and chemical properties and organic matter of the soil in order to examine how termite activity and mounds affect the soil in the toposequence area. 


\section{MATERIALS AND METHODS}

The study area was located in the municipality of Pinheiral, in a sub-basin of the Cachimbal creek (latitudes $22^{\circ} 33^{\prime} \mathrm{S}-22^{\circ} 38^{\prime} \mathrm{S}$, longitudes $43^{\circ} 57^{\prime} \mathrm{W}-44^{\circ} 05^{\prime} \mathrm{W}$ ), on the right bank of the Paraiba do Sul river, in a region known as Medio Paraiba Fluminense with the topographic designation Mar de Morros. The local weather, according to Köppen and Geiger (1938), is Am, a rainy tropical climate, monsoonal, with dry winters. The soils were classified as Inceptsol (Cambissolo Háplico). The area is part of the ecological domain of the Atlantic Forest, with a Lower Montane Rain Forest vegetation type, at an altitude range between 300 and $800 \mathrm{~m}$. The soil in the region consists of unmanaged pastures of species such as Paspalum notatum, and a few native leguminous species. The soil of the area is in different stages of degradation, and inhabited by a large number of termite populations.

Initially, two toposequences characterized by the occurrence of mounds were selected. Each toposequence was divided in shoulder, backslope, and footslope (slope thirds). In each of these sections, four termite mounds were selected for soil sampling according to their external appearance, based on their vitality and the surrounding areas. The mound vitality was evaluated for the presence of termites with an iron digger. Subsequently, the soil around the mounds was sampled. Single samples were collected from around each nest (layers 0.00-0.05 and 0.05-0.10 m), at distances of 0.50 and $1.50 \mathrm{~m}$ from the mound base, the same as used in other studies (Kaschuk et al., 2006; Sarcinelli et al., 2009; Joseph et al., 2013; Sarcinelli et al., 2013). Per mound, a total of four samples were retrieved from the surrounding soil (Figure 1).

Soil samples from the mounds were also taken, air-dried, crumbled, and sieved $(2.0 \mathrm{~mm}$ mesh) to obtain air-dried fine earth. The analyses for physical (soil particle size by the pipette method) and chemical (water $\mathrm{pH}, \mathrm{Ca}^{2+}+\mathrm{Mg}^{2+}, \mathrm{Al}^{3+}, \mathrm{K}^{+}, \mathrm{Na}^{+}, \mathrm{H}+\mathrm{Al}$, and $\mathrm{P}$ ) soil properties were performed as described by Donagema et al. (2011). Organic matter was characterized based on particle size (Cambardella and Elliott, 1992) and chemical fractionation (Swift, 1996), by the technique proposed and modified by Benites et al. (2003).

Data were analyzed using a statistical model for stratified plots in a randomized block design, in which the blocks were represented by the toposequences. For data analysis, the sample points were labelled according to location (mound top, center, and base, and 0.50 and $1.50 \mathrm{~m}$ away from the mound). At first, the data were subjected to analysis of variance to investigate the fundamental premises of analysis of variance, i.e., normality and homoscedasticity of variance, by the Shapiro-Wilk and Bartlett tests, respectively. In a new analysis, the means of the factors indicating significant differences were compared by the Scott-Knott test at $5 \%$ probability, using the statistical software R, version 3.1.1 (R Development Core Team, 2015).

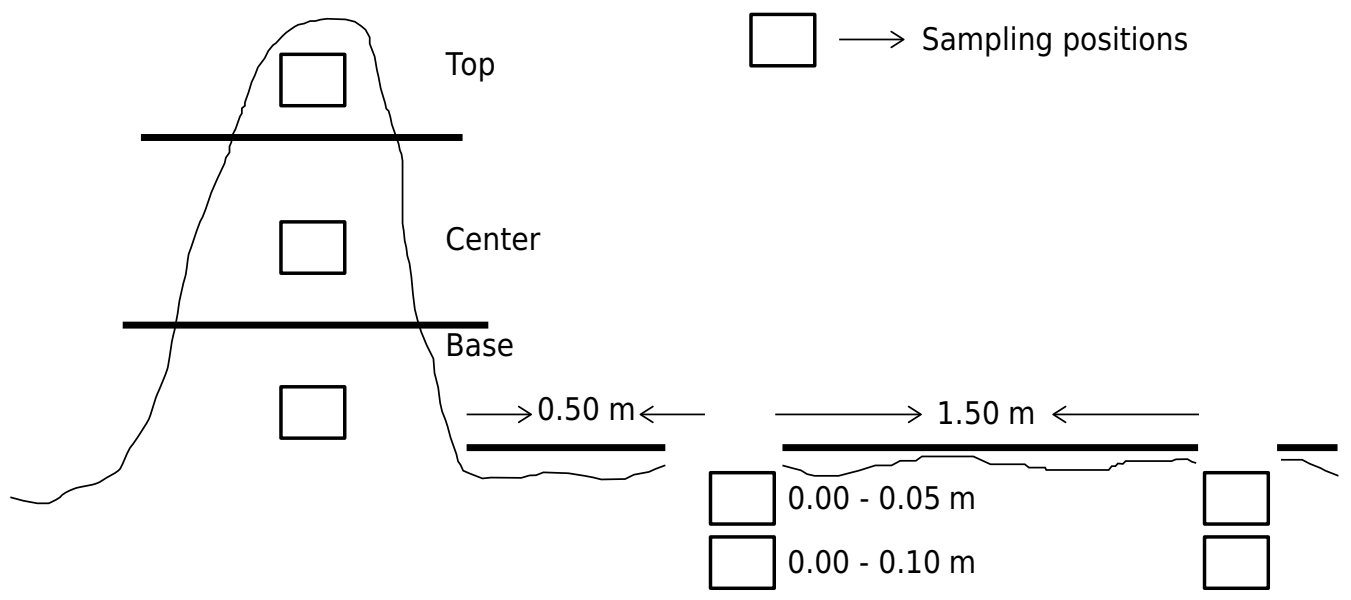

Figure 1. Sampled sections of a termite mound (top, center, and base) and the adjacent soil at two distances and depths. 


\section{RESULTS AND DISCUSSION}

In toposequence 1 , all termite mounds were constructed by the species $C$. cumulans. This group was predominant in all mounds, except in one on the backslope, from which individuals of the genus Velocitermes sp. were also collected. In toposequence 2, all mounds were built by species $C$. cumulans as well, which was the dominant species (Table 1). However, in two termite mounds, four termite genera cohabiting in the mound top were observed.

The termite genera identified in this study are commonly observed in pastures, especially C. cumulans, which has been considered an ecological key species, owing to its abundance in some areas. Moreover, termite mounds shelter many fauna species and sustain some plants that can reproduce and develop within and in the surroundings of the constructions (Redford, 1984). The dominance of this species in the construction of mounds was an advantage for data comparison in this study, since their mounds have the same structural characteristics, aside from the similar feeding habits and similar behavior between sites.

Particle size analysis indicated that the average total sand in adjacent soils was similar at both sampled distances $(0.50$ and $1.50 \mathrm{~m})$ from the mound base, and higher than the mean contents of the termite mound sections (top, center, and base). However, the mean total sand contents did not differ among the sections. This pattern was observed for both soil layers (Table 2). Similar results were observed for the sand fractions, where the fine sand and coarse sand contents, regardless of the sampling layer, were higher $(p<0.05)$ in the adjacent soil than in any mound section. Contrary to the pattern observed for the clay and sand fractions, the average values of the silt fraction did not differ between the mound sections and adjacent soil, regardless of the sampling layer. The mean values of the clay fraction indicate that the mounds contain a high content of this fraction, which is uniformly distributed in constructions, differing from the pattern observed in the adjacent soil, regardless of the distance from the mound base, indicating that termites prefer fine particles for mound building.

The results of this study corroborate those of Peres Filho et al. (1990) and Sarcinelli et al. (2013), who found higher clay contents in mounds than in soils at different sampling distances. A higher clay content in mounds was also reported by Oliveira et al. (2012), but not for the other fractions. Contrary to the findings of these authors, Kaschuk et al. (2006) observed

Table 1. Genera identified in termite mounds in slope thirds of toposequences

\begin{tabular}{|c|c|}
\hline Toposequence 1 & Toposequence 2 \\
\hline \multicolumn{2}{|r|}{ Shoulder } \\
\hline C. cumulans & C. cumulans + Labiotermes $b+$ Subulitermes $m .+$ Velocitermes sp. \\
\hline C. cumulans & C. cumulans + Labiotermes $b+$ Subulitermes $m .+$ Velocitermes sp. \\
\hline C. cumulans & C. cumulans \\
\hline C. cumulans & C. cumulans \\
\hline \multicolumn{2}{|r|}{ Backslope } \\
\hline C. cumulans & Velocitermes sp. \\
\hline C. cumulans & C. cumulans \\
\hline C. cumulans & C. cumulans \\
\hline C. cumulans+Velocitermes sp. & C. cumulans \\
\hline \multicolumn{2}{|r|}{ Footslope } \\
\hline C. cumulans & C. cumulans \\
\hline C. cumulans & C. cumulans \\
\hline C. cumulans & C. cumulans \\
\hline C. cumulans & C. cumulans \\
\hline
\end{tabular}


Table 2. Textural composition of termite mounds and their adjacent soils, in the Mar de Morros region, municipality of Pinheiral, Rio de Janeiro State

\begin{tabular}{|c|c|c|c|c|c|}
\hline Soil & Total sand & Fine sand & Coarse sand & Silt & Clay \\
\hline & \multicolumn{5}{|c|}{$\mathrm{g} \mathrm{kg}^{-1}$} \\
\hline \multicolumn{6}{|c|}{ Layer $0.00-0.05 \mathrm{~m}$} \\
\hline Top & $333 \mathrm{~b}$ & $99 \mathrm{~b}$ & $233 b$ & 227 a & 438 a \\
\hline Center & $328 \mathrm{~b}$ & $108 \mathrm{~b}$ & $220 \mathrm{~b}$ & $229 a$ & $445 a$ \\
\hline Base & $312 b$ & $100 \mathrm{~b}$ & $212 b$ & $238 a$ & 449 a \\
\hline $0.50 \mathrm{~m}$ & 607 a & 156 a & $450 \mathrm{a}$ & $223 a$ & $169 \mathrm{~b}$ \\
\hline $1.50 \mathrm{~m}$ & $609 a$ & 162 a & $446 a$ & $229 a$ & $161 \mathrm{~b}$ \\
\hline CV \% & 7.54 & 16.16 & 10.84 & 10.26 & 8.12 \\
\hline \multicolumn{6}{|c|}{ Thirds } \\
\hline Top & 438 a & $121 \mathrm{a}$ & 302 a & $249 a$ & 318 a \\
\hline Center & $441 \mathrm{a}$ & 132 a & 318 a & $228 a$ & 330 a \\
\hline Base & 438 a & $122 \mathrm{a}$ & 317 a & $211 a$ & $349 a$ \\
\hline CV \% & 2.05 & 9.82 & 5.18 & 11.52 & 3.82 \\
\hline \multicolumn{6}{|c|}{ Layer $0.05-0.10 \mathrm{~m}$} \\
\hline Top & $332 b$ & $99 \mathrm{~b}$ & $233 b$ & $227 a$ & 438 a \\
\hline Center & $328 b$ & $108 \mathrm{~b}$ & $220 \mathrm{~b}$ & $229 a$ & $445 a$ \\
\hline Base & $312 b$ & $100 \mathrm{~b}$ & $212 b$ & $238 a$ & $449 a$ \\
\hline $0.50 \mathrm{~m}$ & $604 a$ & 166 a & $438 a$ & $215 a$ & $180 \mathrm{~b}$ \\
\hline $1.50 \mathrm{~m}$ & 602 a & 165 a & $437 a$ & $214 a$ & $183 \mathrm{~b}$ \\
\hline CV \% & 6.85 & 8.01 & 10.15 & 11.64 & 7.00 \\
\hline \multicolumn{6}{|c|}{ Thirds } \\
\hline Top & 438 a & $131 \mathrm{a}$ & 30.67 a & $244 a$ & 319 a \\
\hline Center & $442 \mathrm{a}$ & $128 \mathrm{a}$ & $31.42 \mathrm{a}$ & $220 a$ & 337 a \\
\hline Base & 427 a & $124 \mathrm{a}$ & $30.35 a$ & $210 a$ & 361 a \\
\hline CV \% & 4.92 & 21.05 & 13.33 & 10.48 & 7.34 \\
\hline
\end{tabular}

Total sand, fine sand (0.05-0.20 mm), coarse sand (0.20-2.0 mm), silt (0.002-0.05 mm), and clay $(<0.002 \mathrm{~mm})$ were determined by the pipette method (Donagema et al., 2011). Averages followed by the same letter, in the same column, did not differ from each other by the Scott-Knott test $(p<0.05)$.

no differences between the clay contents in mounds and the surrounding soils. According to Ackerman et al. (2007), the clay contents were lower and silt and sand contents higher in mounds than in the surrounding soils. Although there is still no consensus among authors about how termites select the soil particle size, according to Donovan et al. (2001), the higher clay contents in mounds than in surrounding soil probably results from the preference for fine particles for the construction of termite mounds.

With respect to the nutrient content in the various mound sections, the highest nutrient content was generally observed at the base (Table 3). This pattern can be explained by the fact that all mounds of the toposequences were constructed by the same species, C. cumulans, and mounds of these species are characterized by the accumulation of large amounts of plant material at the mound base (Sanchez et al., 1989). The average $\mathrm{pH}\left(\mathrm{H}_{2} \mathrm{O}\right)$ values for soils $(0.00-0.05 \mathrm{~m}$ layer) were higher $(\mathrm{p}<0.05)$ than in the mounds, while these values did not differ between the top, center, and base sections. However, when the average $\mathrm{pH}$ of mound material was compared with that of soils in the $0.05-0.10 \mathrm{~m}$ layer, there was no significant difference between the adjacent soils and mound sections.

The $\mathrm{Al}^{3+}$ contents differed $(p<0.05)$ between mound sections in the $0.00-0.05 \mathrm{~m}$ layer. Highest values $(p<0.05)$ were observed in the center and base sections, while the value observed in the top section was comparable to that of the soils, which did not differ 
Table 3. Chemical properties of termite mounds and surrounding soils in the 0.00-0.05 and 0.05$0.10 \mathrm{~m}$ layers, Mar de Morros, municipality of Pinheiral, Rio de Janeiro State

\begin{tabular}{|c|c|c|c|c|c|c|}
\hline Soil & $\mathrm{pH}\left(\mathrm{H}_{2} \mathrm{O}\right)$ & $\mathrm{Al}^{3+}$ & H & H+Al & $\%$ Al & $\mathbf{P}$ \\
\hline & & \multicolumn{4}{|c|}{$\mathrm{cmol}_{\mathrm{c}} \mathrm{kg}^{-1}$} & $\mathrm{mg} \mathrm{kg}^{-1}$ \\
\hline \multicolumn{7}{|c|}{ Layer $0.00-0.05 \mathrm{~m}$} \\
\hline Top & $5.45 \mathrm{~b}$ & $0.05 \mathrm{~b}$ & $5.63 \mathrm{~b}$ & $5.68 \mathrm{~b}$ & $0.15 \mathrm{~b}$ & $0.06 a$ \\
\hline Center & $5.39 \mathrm{~b}$ & $0.07 \mathrm{a}$ & $5.61 b$ & $5.69 \mathrm{~b}$ & $0.22 \mathrm{a}$ & $0.05 a$ \\
\hline Base & $5.32 \mathrm{~b}$ & $0.07 \mathrm{a}$ & $6.94 \mathrm{a}$ & $7.02 \mathrm{a}$ & $0.17 \mathrm{~b}$ & $0.11 \mathrm{a}$ \\
\hline $0.50 \mathrm{~m}$ & $5.62 \mathrm{a}$ & $0.04 \mathrm{~b}$ & $4.94 \mathrm{C}$ & $4.98 \mathrm{C}$ & $0.23 \mathrm{a}$ & $0.00 \mathrm{~b}$ \\
\hline $1.50 \mathrm{~m}$ & $5.64 \mathrm{a}$ & $0.04 \mathrm{~b}$ & $4.76 \mathrm{c}$ & $4.80 \mathrm{c}$ & $0.25 a$ & $0.00 \mathrm{~b}$ \\
\hline CV \% & 2.89 & 29.79 & 8.05 & 8.49 & 21.82 & 30.23 \\
\hline \multicolumn{7}{|c|}{ Thirds } \\
\hline Top & $5.50 \mathrm{a}$ & $0.05 a$ & $5.82 \mathrm{a}$ & $5.87 \mathrm{a}$ & $0.20 \mathrm{a}$ & $0.03 a$ \\
\hline Center & $5.45 a$ & $0.05 a$ & $5.51 \mathrm{a}$ & $5.56 a$ & $0.20 \mathrm{a}$ & $0.01 \mathrm{a}$ \\
\hline Base & $5.49 a$ & $0.06 a$ & $5.40 \mathrm{a}$ & $5.47 \mathrm{a}$ & $0.22 \mathrm{a}$ & $0.01 \mathrm{a}$ \\
\hline CV \% & 1.03 & 11.54 & 10.73 & 7.69 & 13.40 & 51.73 \\
\hline \multicolumn{7}{|c|}{ Layer 0.05-0.10 m } \\
\hline Top & $5.45 a$ & $0.05 a$ & $5.63 \mathrm{~b}$ & $5.68 \mathrm{~b}$ & $0.15 \mathrm{~b}$ & $0.06 a$ \\
\hline Center & $5.39 a$ & $0.07 \mathrm{a}$ & $5.61 \mathrm{~b}$ & $5.69 \mathrm{~b}$ & $0.22 \mathrm{~b}$ & $0.05 \mathrm{a}$ \\
\hline Base & $5.32 \mathrm{a}$ & $0.07 \mathrm{a}$ & $6.94 a$ & $7.02 \mathrm{a}$ & $0.17 \mathrm{~b}$ & $0.11 \mathrm{a}$ \\
\hline $0.50 \mathrm{~m}$ & $5.40 \mathrm{a}$ & $0.06 a$ & $5.12 b$ & $5.18 \mathrm{~b}$ & $0.48 a$ & $0.00 \mathrm{~b}$ \\
\hline $1.50 \mathrm{~m}$ & $5.39 a$ & $0.07 \mathrm{a}$ & $5.08 \mathrm{~b}$ & $5.15 \mathrm{~b}$ & $0.62 a$ & $0.00 \mathrm{~b}$ \\
\hline CV \% & 2.01 & 31.27 & 7.94 & 7.84 & 58.49 & 9.36 \\
\hline \multicolumn{7}{|c|}{ Thirds } \\
\hline Top & $5.41 \mathrm{a}$ & $0.06 a$ & $5.88 a$ & $5.94 \mathrm{a}$ & $0.26 a$ & $0.07 a$ \\
\hline Center & $5.33 \mathrm{a}$ & $0.07 a$ & $5.68 \mathrm{a}$ & $5.75 a$ & $0.47 a$ & $0.03 a$ \\
\hline Base & $5.42 \mathrm{a}$ & 0.07 a & $5.47 a$ & $5.54 a$ & $0.31 \mathrm{a}$ & $0.03 \mathrm{a}$ \\
\hline CV \% & 1.19 & 24.62 & 9.01 & 8.95 & 73.47 & 14.28 \\
\hline
\end{tabular}

$\mathrm{pH}\left(\mathrm{H}_{2} \mathrm{O}\right): \mathrm{pH}$ in water, $\mathrm{v} / \mathrm{v} 1: 2.5 ; \mathrm{Al}^{3+}$ extracted with $1 \mathrm{~mol} \mathrm{~L}^{-1} \mathrm{KCl} ; \mathrm{H}+\mathrm{Al}$ : determined by calcium acetate at $\mathrm{pH}$ 7.0; P extracted by Mehlich-1 (Donagema et al., 2011). Averages followed by same letter, in the same column, do not differ from each other by the Scott-Knott test $(p<0.05)$.

between the sampled distances. In contrast, for the 0.05-0.10 m layer, no difference was found between mound sections and surrounding soil. In contrast to these findings, Sarcinelli et al. (2009) observed lower $\mathrm{Al}^{3+}$ values in the adjacent soil than in the mounds. According to these authors, the lower $\mathrm{Al}^{3+}$ contents in mounds than in surrounding soils are due to the complexation of soil organic matter and $\mathrm{Al}^{3+}$ precipitation.

With regard to the chemical variables related to acidity, the average values for $\mathrm{H}+\mathrm{Al}$, which represent the potential soil acidity, were higher $(p<0.05)$ at the mound base, differing from the top and center sections. These values were still higher than those of the 0.00-0.05 m soil layer. In the 0.05-0.10 m layer, the analysis showed that $\mathrm{H}+\mathrm{Al}$ values were higher in the soil, but only equivalent to those observed in the mound top and center, which are lower than at the mound base. In the 0.00-0.05 m layer, the $\mathrm{Al}^{3+}$ content (\%) in mounds differed between sections, and was higher in the center $(p<0.05)$ than the mound top and base. The same was observed in the soils at both distances. However, in the 0.05-0.10 m layer, there was no difference between the mound sections, unlike in the soil, where values were higher $(p<0.05)$ than in the mounds. The higher coefficient of variation of this property compared to the others mentioned reflects the greater inconstancy of the values. According to Oliveira et al. (2012), the top of the mounds (external part of the top section) is more resistant due to the incorporation of a larger quantity of saliva during construction; as a result, higher $\mathrm{pH}$ values are observed in this section. Even termites that do not ingest soil, they mix soil particles with saliva with their jaws for the construction of the outer mound walls (Sarcinelli et al., 2009). 
In both layers, the $\mathrm{P}$ contents did not differ among the mound sections and were higher $(p<0.05)$ than those in the soil at both sampling distances. As with all the other properties listed above, there was no difference between the respective means of the topographic position of the slope thirds. In a comparison of the P contents in termite mounds and surrounding soil, Ackerman et al. (2007) stated no difference between nutrient contents. The P content is generally higher in mounds of termites that feed on grasses than in the adjacent soils, which is probably due to the incorporation of feces in the mound material (López-Hernández et al., 2006). According to Rückamp et al. (2010), P levels vary between the different mound sections. These authors observed gradients in $\mathrm{P}$ composition between the different parts of Cornitermes sp. mounds. However, Oliveira et al. (2012) report that the higher P content in mounds is related to the amount of clay in the construction, preventing the loss of available $P$.

The levels of $\mathrm{Ca}^{2+}$ in the mound base were higher $(\mathrm{p}<0.05)$ than those in the mound top and center and in the adjacent soils, at both distances from the base, in the 0.00-0.05 $\mathrm{m}$ layer. The top and center contents were higher at both distances in the 0.00-0.05 m layer (Table 4). The $\mathrm{Mg}^{2+}$ and $\mathrm{K}^{+}$levels in the upper layer did not differ between the mound sections, but were higher $(p<0.05)$ than those in the soil, with no difference between the two sampling distances from the base. In the 0.05-0.10 m layer however, only $\mathrm{K}^{+}$ differed from the pattern observed in the other layer.

The average $\mathrm{K}^{+}$contents in mound sections are almost twice as high as in the surrounding soil. The soil values were similar between sampling distances. Higher $\mathrm{Ca}^{2+}$ contents were reported by Ackerman et al. (2007) in the soil, and higher $\mathrm{K}^{+}$in the mounds. Even in $\mathrm{K}^{+}$-poor soils, the mound material is richer in $\mathrm{K}^{+}$, with three times higher contents than in the soil (Joseph et al., 2013). Thus, considering the $\mathrm{K}^{+}$mobility in soil, higher contents

Table 4. Chemical properties of termite mounds and the surrounding soil in the 0.00-0.05 and 0.05-0.10 m layers, Mar de Morros region, municipality of Pinheiral, Rio de Janeiro State

\begin{tabular}{|c|c|c|c|c|c|c|c|}
\hline Soil & $\mathrm{Ca}^{2+}$ & $\mathrm{Mg}^{2+}$ & $\mathbf{K}^{+}$ & $\mathrm{Na}^{+}$ & $\mathbf{S}$ & $\mathbf{T}$ & V \% \\
\hline \multicolumn{8}{|c|}{$\mathrm{cmol}_{\mathrm{c}} \mathrm{kg}^{-1}$} \\
\hline \multicolumn{8}{|c|}{ Layer 0.00-0.05 m } \\
\hline Top & $3.90 \mathrm{~b}$ & $5.48 \mathrm{a}$ & $0.37 \mathrm{a}$ & $0.02 \mathrm{a}$ & $9.78 \mathrm{~b}$ & $15.46 \mathrm{~b}$ & $63 a$ \\
\hline Center & $3.95 \mathrm{~b}$ & $5.34 \mathrm{a}$ & $0.40 \mathrm{a}$ & $0.02 \mathrm{a}$ & $9.72 \mathrm{~b}$ & $15.41 \mathrm{~b}$ & $63 a$ \\
\hline Base & $4.96 \mathrm{a}$ & $5.87 \mathrm{a}$ & $0.48 \mathrm{a}$ & $0.03 \mathrm{a}$ & $11.36 \mathrm{a}$ & $18.37 \mathrm{a}$ & $62 a$ \\
\hline $0.50 \mathrm{~m}$ & $2.58 \mathrm{c}$ & $3.10 \mathrm{~b}$ & $0.20 \mathrm{~b}$ & $0.03 a$ & $5.94 \mathrm{C}$ & $10.62 \mathrm{c}$ & $52 b$ \\
\hline $1.50 \mathrm{~m}$ & $2.39 \mathrm{C}$ & $2.80 \mathrm{~b}$ & $0.28 \mathrm{~b}$ & $0.03 a$ & $5.53 \mathrm{C}$ & $10.06 \mathrm{c}$ & $50 \mathrm{~b}$ \\
\hline CV \% & 9.75 & 11.33 & 36.69 & 80.81 & 11.69 & 8.52 & 10.42 \\
\hline \multicolumn{8}{|c|}{ Thirds } \\
\hline Top & $3.58 \mathrm{a}$ & $4.49 a$ & $0.38 a$ & $0.02 \mathrm{a}$ & $8.49 a$ & $14.23 \mathrm{a}$ & $58 a$ \\
\hline Center & $3.57 \mathrm{a}$ & $4.63 \mathrm{a}$ & $0.34 \mathrm{a}$ & $0.03 a$ & 8.58 a & $14.04 \mathrm{a}$ & $58 a$ \\
\hline Base & $3.51 \mathrm{a}$ & $4.44 \mathrm{a}$ & $0.33 a$ & $0.03 a$ & $8.32 \mathrm{a}$ & $13.69 \mathrm{a}$ & $58 \mathrm{a}$ \\
\hline CV \% & 6.01 & 18.48 & 25.80 & 62.72 & 6.48 & 6.92 & 1.82 \\
\hline \multicolumn{8}{|c|}{ Layer 0.05-0.10 m } \\
\hline Top & $3.90 \mathrm{~b}$ & $5.48 \mathrm{a}$ & $0.37 \mathrm{~b}$ & $0.02 \mathrm{a}$ & $9.78 \mathrm{~b}$ & $15.46 \mathrm{~b}$ & $63 a$ \\
\hline Center & $3.95 \mathrm{~b}$ & $5.34 \mathrm{a}$ & $0.40 \mathrm{~b}$ & $0.02 \mathrm{a}$ & $9.72 \mathrm{~b}$ & $15.41 \mathrm{~b}$ & $63 a$ \\
\hline Base & $4.96 \mathrm{a}$ & $5.87 \mathrm{a}$ & $0.49 a$ & $0.03 a$ & $11.36 \mathrm{a}$ & $18.37 \mathrm{a}$ & $62 a$ \\
\hline $0.50 \mathrm{~m}$ & $2.36 \mathrm{c}$ & $2.57 \mathrm{~b}$ & $0.16 \mathrm{c}$ & $0.04 a$ & $5.12 \mathrm{c}$ & $10.30 \mathrm{c}$ & $49 a$ \\
\hline $1.50 \mathrm{~m}$ & $2.19 \mathrm{C}$ & $2.33 \mathrm{~b}$ & $0.16 \mathrm{c}$ & $0.03 a$ & $4.71 \mathrm{C}$ & $9.86 \mathrm{c}$ & $47 a$ \\
\hline CV \% & 9.72 & 12.57 & 18.89 & 77.49 & 9.11 & 5.69 & 4.93 \\
\hline \multicolumn{8}{|c|}{ Thirds } \\
\hline Top & $3.53 a$ & $4.26 a$ & $0.31 \mathrm{a}$ & $0.03 a$ & $8.13 \mathrm{a}$ & $14.07 \mathrm{a}$ & $57 a$ \\
\hline Center & $3.47 \mathrm{a}$ & $4.47 \mathrm{a}$ & $0.32 \mathrm{a}$ & $0.03 a$ & $8.29 a$ & $14.04 \mathrm{a}$ & $57 a$ \\
\hline Base & $3.42 \mathrm{a}$ & $4.23 a$ & $0.31 \mathrm{a}$ & $0.03 a$ & $8.00 \mathrm{a}$ & $13.05 \mathrm{a}$ & $56 a$ \\
\hline CV \% & 3.80 & 16.76 & 14.03 & 41.28 & 9.38 & 6.53 & 4.62 \\
\hline
\end{tabular}

$\mathrm{Ca}^{2+}$ and $\mathrm{Mg}^{2+}$ : $1 \mathrm{~mol} \mathrm{~L}{ }^{-1} \mathrm{KCl}$ extractant; $\mathrm{K}^{+}$: Mehlich-1 extractant; $\mathrm{S}$ : sum of bases, T: cation exchange capacity; base saturation [V = $\left.(\mathrm{SB} / \mathrm{T}) \times 100\right]$, where $\mathrm{T}[\mathrm{CEC} \mathrm{pH} 7 \mathrm{SB}+(\mathrm{H}+\mathrm{Al})$ ] (Donagema et al., 2011). Averages followed by same letter, in the same column, do not differ from each other by the Scott-Knott test $(p<0.05)$. 
of this nutrient in mounds may benefit the soil as a result of translocation and leaching from degrading termite mounds.

In relation to the sum of bases $(\mathrm{S})$ and cation exchange capacity of the soil $(\mathrm{T})$, average values were higher in the mound base $(p<0.05)$ than the other sections, which in turn, differed from the surrounding soils; for the latter, independent of the sampling distance, $\mathrm{S}$ and T were lower. This pattern was also observed for samples of both soil layers. Similar results were reported by Peres Filho et al. (1990). The highest average T values correspond mostly to essential cations such as $\mathrm{Ca}^{2+}, \mathrm{Mg}^{2+}$, and $\mathrm{K}^{+}$, which are nutrients that promote plant nutrition (Ronquim, 2010). The base saturation levels $(\mathrm{V} \%)$ differed $(p<0.05)$ only in the $0.00-0.05 \mathrm{~m}$ layer, where the mound sections showed the highest levels, above $60 \%$, no differences were observed for any of the properties listed above in relation to the landscape position. The higher nutrient contents in the termite mounds than in surrounding soil indicates that they create "islands" (Lavelle et al., 1997; Pennisi, 2015), within which nutrients are concentrated and can, as a consequence of mound degradation, be released into the soil over time.

The contents of total organic carbon (TOC) in the 0.00-0.05 m layer (Table 5) differed $(p<0.05)$ between the mound sections, where higher contents were observed than in the soil. The measured contents of the mound base were higher than those of the top and center sections, especially when compared to the soil, for both distances. For the TOC distribution in the landscape, there was no difference between the slope thirds. The same pattern was observed in the $0.05-0.10 \mathrm{~m}$ layer, with lower contents in soil, with a slight decrease from the nearer to the farther sampled distances.

The increase in carbon content in the mound base is related to the species that builds the mounds. The nests have a core consisting of carton material, composed of organic matter, soil and saliva, and covered by a dark substance secreted by termites (Redford, 1984;

Table 5. Total organic carbon (TOC), particulate organic carbon (POC), and mineral-associated organic carbon (MOC) in termite mounds and surrounding soil, in the 0.00-0.05 and 0.05-0.10 m layers, Mar de Morros region, municipality of Pinheiral, Rio de Janeiro State

\begin{tabular}{|c|c|c|c|}
\hline Soil & TOC & POC & MOC \\
\hline & 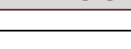 & $-\mathrm{g} \mathrm{kg}^{-1}$ & \\
\hline \multicolumn{4}{|c|}{ Layer 0.00-0.05 m } \\
\hline Top & $20.37 b$ & $8.26 \mathrm{~b}$ & $13.14 \mathrm{a}$ \\
\hline Center & $21.99 b$ & $10.71 \mathrm{~b}$ & $18.60 \mathrm{a}$ \\
\hline Base & $38.46 a$ & $49.32 \mathrm{a}$ & $21.97 \mathrm{a}$ \\
\hline $0.50 \mathrm{~m}$ & $13.51 \mathrm{C}$ & $2.54 \mathrm{C}$ & $1.50 \mathrm{~b}$ \\
\hline $1.50 \mathrm{~m}$ & $12.88 \mathrm{C}$ & $2.24 \mathrm{C}$ & $1.23 \mathrm{~b}$ \\
\hline CV \% & 20.64 & 14.60 & 16.46 \\
\hline \multicolumn{4}{|c|}{ Thirds } \\
\hline Top & $20.64 \mathrm{a}$ & $12.33 \mathrm{a}$ & $8.32 \mathrm{a}$ \\
\hline Center & $21.56 a$ & $12.52 \mathrm{a}$ & $12.77 \mathrm{a}$ \\
\hline Base & $22.13 \mathrm{a}$ & $18.99 \mathrm{a}$ & $12.78 \mathrm{a}$ \\
\hline CV \% & 15.64 & 10.50 & 14.92 \\
\hline \multicolumn{4}{|c|}{ Layer 0.05-0.10 m } \\
\hline Top & $20.37 b$ & $8.26 \mathrm{~b}$ & $13.15 \mathrm{a}$ \\
\hline Center & $21.99 b$ & $10.72 b$ & $18.60 \mathrm{a}$ \\
\hline Base & $38.46 a$ & $49.32 \mathrm{a}$ & $21.97 \mathrm{a}$ \\
\hline $0.50 \mathrm{~m}$ & $11.68 \mathrm{c}$ & $1.75 \mathrm{a}$ & $1.11 \mathrm{~b}$ \\
\hline $1.50 \mathrm{~m}$ & $11.67 \mathrm{C}$ & $1.76 \mathrm{a}$ & $1.07 \mathrm{~b}$ \\
\hline CV \% & 6.73 & 9.75 & 12.49 \\
\hline \multicolumn{4}{|c|}{ Thirds } \\
\hline Top & $19.73 \mathrm{a}$ & $12.17 \mathrm{a}$ & $8.21 \mathrm{a}$ \\
\hline Center & $21.02 \mathrm{a}$ & $12.33 \mathrm{a}$ & $12.72 \mathrm{a}$ \\
\hline Base & $21.75 \mathrm{a}$ & $18.59 \mathrm{a}$ & $12.60 \mathrm{a}$ \\
\hline CV \% & 5.21 & 2.71 & 3.88 \\
\hline
\end{tabular}

TOC, POC, and MOC were determined by the Cambardella and Elliott (1992) method. Averages followed by the same letter in the same column do not differ from each other by the Scott-Knott test $(p<0.05)$. 
Sanchez et al., 1989). From the values of the carbon contents, it can be inferred that the content of organic matter is highest in the mound base, directly influenced by some of the chemical properties, as confirmed by the $T$ values. To date, no studies on the fractionation of organic matter in termite mounds were published in the literature.

The particle size fractionation of organic matter showed that particulate organic carbon (POC), which is associated with the sand fraction, follows the same pattern as TOC, with highest $(p<0.05)$ values in the mounds. However, for this parameter, the contents in the mound base are far higher than at the other sampling points, an approximate six-fold increase compared to the top levels. The variables that did not meet the Anova premises (POC and MOC) were subsequently subjected to transformation by the Box and Cox method (1964). The soil values are lower than those for the mound top and center. The highest POC values at the mound base are also related to the high concentration of plant material within the mound base.

When observing the organic carbon associated with minerals (MOC) in the 0.00-0.05 $\mathrm{m}$ layer, no differences were observed between the mound sections, although the contents of the respective sections followed a pattern of top-to-base increase. Nevertheless, the mound contents were higher $(p<0.05)$ than in those of the soil, at both distances from the base. A similar statistical pattern was observed in the 0.05-0.10 m layer, and the sharp decrease in soil values is worth mentioning. According to Kaschuk et al. (2006) and Sarcinelli et al. (2009), it is possible that clay minerals are modified by termites since the soil particles are processed in their mandibles with saliva during transportation for mound construction or pass through their digestive tract.

Similarly, no differences were identified in MOC levels, when considering the topographic position in the evaluated layers. No studies have addressed the physical fractionation of organic matter in mounds; however, the values observed in this study show that POC and $\mathrm{MOC}$ in the mound bases are higher than those quantified in soil under grasses by other authors, while soil values presented in this study are lower (Carmo et al., 2012; Loss et al., 2014).

For the humic substances, a distinctive pattern was found for the levels of the different fractions. Carbon of the humic acid fraction (C-HAF) in the 0.00-0.05 m layer showed a partitioning with a significant interaction (5\% level) (Table 6). Each soil component was analyzed (mound sections and surrounding soils) in the thirds of the toposequences. For this variable, no differences were observed between soil components in relation to the topographic position, neither among mound sections (top, center, and base), nor the soil of the two sampling distances (Table 6). The comparative analysis of the components within each third, however, indicated significant differences.

Table 6. Carbon content in humic acid fractions (C-HAF) and carbon from the fulvic acid fraction (C-FAF) in termite mounds and adjacent soils in the Mar de Morros region, Municipality of Pinheiral, Rio de Janeiro State

\begin{tabular}{|c|c|c|c|}
\hline \multirow{3}{*}{ Soil } & Shoulder & Backslope & Footslope \\
\hline & \multicolumn{3}{|c|}{ Thirds - layer 0.00-0.05 m } \\
\hline & \multicolumn{3}{|c|}{ C-HAF } \\
\hline & & $-\mathrm{g} \mathrm{kg}^{-1}$ & \\
\hline Top & $2.82 \mathrm{~A} \mathrm{~b}$ & $2.95 \mathrm{~A} \mathrm{~b}$ & $2.90 \mathrm{~A} \mathrm{~b}$ \\
\hline Center & $3.24 \mathrm{~A} \mathrm{~b}$ & $4.05 \mathrm{~A} \mathrm{~b}$ & $2.28 \mathrm{~A} \mathrm{~b}$ \\
\hline Base & $7.54 \mathrm{~A} \mathrm{a}$ & $7.38 \mathrm{~A} \mathrm{a}$ & $9.87 \mathrm{~A} \mathrm{a}$ \\
\hline $0.50 \mathrm{~m}$ & $2.05 \mathrm{~A} \mathrm{~b}$ & $1.82 \mathrm{~A} \mathrm{C}$ & $1.76 \mathrm{~A} \mathrm{~b}$ \\
\hline $1.50 \mathrm{~m}$ & $1.86 \mathrm{~A} \mathrm{~b}$ & $1.52 \mathrm{~A} \mathrm{C}$ & $1.50 \mathrm{~A} \mathrm{~b}$ \\
\hline CV \% Thirds & & & \\
\hline CV \% Soil & & & \\
\hline
\end{tabular}

C-HAF and C-FAF determined according to Swift (1996), technique proposed and modified by Benites et al. (2003). Averages followed by the same capital letter in the same line do not differ from each other; averages followed by the same lowercase letter in the same column do not differ from each other by the Scott-Knott test $(p<0.05)$. 
In the slope shoulder, the C-HAF contents were highest $(p<0.05)$ for the mound base, while the other two sections had similar values to the soil at both distances. In the backslope, the highest contents $(p<0.05)$ of this fraction were also observed at the mound base, however, values in the top and center were similar and higher $(p<0.05)$ than in the soil. There was no difference between distances. In the lower third, C-HAF contents were similar to those observed in the other two; the highest values were observed in the mound base, and no difference for the other soil components.

The highest C-HAF contents were observed in the $0.05-0.10 \mathrm{~m}$ layer in the mound section $(p<0.05)$. Highest values were found at the base and the lowest values in the soil at both distances. The results of this study corroborate those of Pinheiro et al. (2013), who evaluated seasonal variations of humic substances in the same area.

The carbon content of the fulvic acid fraction (C-FAF) at both sampling layers differed between the mound sections, with higher values $(p<0.05)$ observed at the mound base (Table 7). The lowest values were recorded in the soil at both sampling distances $(0.50$ and $1.50 \mathrm{~m})$. There was no difference in topographical position between the thirds. Pinheiro et al. (2013) reported decreasing values in the mound section, equal to those observed in the surrounding soil in the summer and winter seasons. In the soil, they observed values lower than those reported in this study.

The analysis of carbon humic fraction (HUM-C) showed a pattern distinct from the other fractions, since the partitioning of the interaction indicated significance at $5 \%$ at both two sampled layers (Table 8). The analysis of soil components (mound sections and adjacent soils) in the thirds shows that there was no difference between the mound top and center. However, HUM-C contents of the mound base showed that this property was significantly different in the different mound sections, where a pattern of increasing values from base to top thirds is observed. However, in the adjacent soils, no differences were observed between the toposequence thirds. Other authors mentioned higher HUM-C contents in mounds compared to the observations in this study (Pinheiro et al., 2013). The highest content of this fraction found in the mound base is probably because the base contains the highest concentration of individuals of the colony, where organic matter is enriched by secretions as well as by mortality at a younger stage. Studies on humic substances

Table 7. Carbon content fulvic acid fraction (C-FAF) in termite mounds and adjacent soils in the Mar de Morros region, Municipality of Pinheiral, Rio de Janeiro State

\begin{tabular}{|c|c|c|c|}
\hline \multirow{2}{*}{ Soil } & Shoulder & Backslope & Footslope \\
\hline & C-FAF & C-FAF & C-HAF \\
\hline & \multicolumn{3}{|c|}{$\mathrm{g} \mathrm{kg}^{-1}$} \\
\hline & $0.00-0.05 \mathrm{~m}$ & \multicolumn{2}{|c|}{$0.05-0.10 \mathrm{~m}$} \\
\hline Top & $2.89 \mathrm{~b}$ & $2.89 \mathrm{~b}$ & $2.89 \mathrm{~b}$ \\
\hline Center & $2.85 \mathrm{~b}$ & $2.85 \mathrm{~b}$ & $3.29 \mathrm{~b}$ \\
\hline Base & $4.70 \mathrm{a}$ & $4.70 \mathrm{a}$ & $8.26 \mathrm{a}$ \\
\hline $0.50 \mathrm{~m}$ & $1.70 \mathrm{c}$ & $1.66 \mathrm{c}$ & $1.44 \mathrm{C}$ \\
\hline $1.50 \mathrm{~m}$ & $1.58 \mathrm{c}$ & $1.68 \mathrm{c}$ & $1.33 \mathrm{c}$ \\
\hline CV \% & 11.85 & 11.13 & 19.10 \\
\hline \multicolumn{4}{|l|}{ Thirds } \\
\hline Top & $2.62 a$ & $2.59 a$ & $3.35 \mathrm{a}$ \\
\hline Center & $2.67 \mathrm{a}$ & $2.68 \mathrm{a}$ & $3.38 \mathrm{a}$ \\
\hline Base & $2.96 \mathrm{a}$ & $3.00 \mathrm{a}$ & $3.60 \mathrm{a}$ \\
\hline CV \% & 22.22 & 22.52 & 17.72 \\
\hline
\end{tabular}

C-HAF and C-FAF determined according to Swift (1996), technique proposed and modified by Benites et al. (2003). Averages followed by the same capital letter in the same line do not differ from each other; averages followed by the same lowercase letter in the same column do not differ from each other by the Scott-Knott test $(p<0.05)$. 
Table 8. Contents of carbon in the humin fraction (HUM-C) in termite mounds and adjacent soils in the Mar de Morros region, municipality of Pinheiral, Rio de Janeiro State

\begin{tabular}{|c|c|c|c|}
\hline \multirow{2}{*}{ Soil } & Shoulder & Backslope & Footslope \\
\hline & \multicolumn{3}{|c|}{ HUM-C } \\
\hline & \multicolumn{3}{|c|}{$\mathrm{g} \mathrm{kg}^{-1}$} \\
\hline \multicolumn{4}{|c|}{ Thirds - 0.00-0.05 m } \\
\hline Top & $14.66 \mathrm{~A} \mathrm{~b}$ & $15.06 \mathrm{~A} \mathrm{~b}$ & $16.00 \mathrm{~A} \mathrm{~b}$ \\
\hline Center & $14.91 \mathrm{~A} \mathrm{~b}$ & $16.22 \mathrm{~A} \mathrm{~b}$ & $15.64 \mathrm{~A} \mathrm{~b}$ \\
\hline Base & $28.28 \mathrm{Ca}$ & $35.21 \mathrm{~B} \mathrm{a}$ & $43.90 \mathrm{~A} \mathrm{a}$ \\
\hline $0.50 \mathrm{~m}$ & $9.35 \mathrm{AC}$ & $8.10 \mathrm{~A} \mathrm{C}$ & $8.33 \mathrm{AC}$ \\
\hline $1.50 \mathrm{~m}$ & $9.57 \mathrm{~A} \mathrm{C}$ & $7.73 \mathrm{AC}$ & $8.50 \mathrm{AC}$ \\
\hline CV \% & & \multicolumn{2}{|c|}{3.69} \\
\hline CV \% & & \multicolumn{2}{|c|}{10.03} \\
\hline \multicolumn{4}{|c|}{ Thirds - 0.05-0.10 m } \\
\hline Top & $14.66 \mathrm{~A} \mathrm{~b}$ & $15.06 \mathrm{~A} \mathrm{~b}$ & $16.00 \mathrm{~A} \mathrm{~b}$ \\
\hline Center & $14.69 \mathrm{~A} \mathrm{~b}$ & $16.20 \mathrm{~A} \mathrm{~b}$ & $15.64 \mathrm{~A} \mathrm{~b}$ \\
\hline Base & $28.28 \mathrm{C} \mathrm{a}$ & $35.21 \mathrm{~B} \mathrm{a}$ & $43.90 \mathrm{~A} \mathrm{a}$ \\
\hline $0.50 \mathrm{~m}$ & $9.17 \mathrm{~A} \mathrm{C}$ & $7.05 \mathrm{AC}$ & $7.60 \mathrm{AC}$ \\
\hline $1.50 \mathrm{~m}$ & $9.71 \mathrm{AC}$ & $6.87 \mathrm{AC}$ & $6.74 \mathrm{AC}$ \\
\hline CV \% Thirds & & \multicolumn{2}{|c|}{5.68} \\
\hline CV \% Soil & & \multicolumn{2}{|c|}{10.04} \\
\hline
\end{tabular}

HUM-C determined according to Swift (1996), technique proposed and modified by Benites et al. (2003). Averages followed by the same capital letter in the same line do not differ from each other; averages followed by the same lowercase letter in the same column do not differ from each other by the Scott-Knott test $(p<0.05)$.

in the soil under different systems revealed higher HUM-C contents in relation to other fractions (Canellas et al., 2000; Cunha et al., 2007; Silva et al., 2012).

For the HUM-C contents in the toposequence shoulder, in the 0.00-0.05 m layer, differences were observed in soil components, and the contents were highest $(p<0.05)$ in the mound base. The lowest values were observed in the surrounding soil, and this pattern was repeated in samples of the $0.05-0.10 \mathrm{~m}$ layer. In the backslope and footslope, the contents in soil components followed the same statistical distribution, with the highest values $(p<0.05)$ at the mound base, differing from the other thirds and the lower contents in the soils, in both sampling layers. The organic matter fractions in different soils of a toposequence were analyzed by Canellas et al. (2000), who found a higher percentage of humic substances in the shoulder and backslope in relation to the lower third of that relief. For the nutrient contents observed in the termite mounds, it is worth mentioning that the compositions, structural forms, and time periods during which these structures persist determine their local impacts on the processes that sustain the services of the soil ecosystem (Lavelle et al., 2016).

\section{CONCLUSIONS}

Termite mounds constructed by $C$. cumulans accumulate a higher percentage of clay, evenly distributed in the mound sections, compared to the adjacent soil, and also contain higher contents of macronutrients $\left(\mathrm{Ca}^{2+}, \mathrm{Mg}^{2+}\right.$, and $\left.\mathrm{K}^{+}\right)$.

Mound base contains the highest carbon contents, either by associations with the sand and mineral fractions or in relation to the fractions of humic substances. The humin $\mathrm{C}$ contents differed from that of the other fractions within the landscape.

Termite mounds perform important services in the ecosystem by accumulating nutrients in mounds, although more studies are necessary to improve the understanding about the dynamics of these nutrients in the soil. 


\section{ACKNOWLEDGEMENTS}

We thank the National Council for Scientific and Technological Development (CNPq) and the Foundation for Research Support of the State of Rio de Janeiro (Faperj) for granting a postdoctoral scholarship and supporting the first author. We also thank Prof. Carlos Eduardo Gabriel Menezes of the Nilo Peçanha Federal Institute.

\section{REFERENCES}

Ackerman IL, Teixeira WG, Riha SJ, Lehmann J, Fernandes ECM. The impact of mound-building termites on surface soil properties in a secondary forest of Central Amazonia. Appl Soil Ecol. 2007;37:267-76. https://doi.org/10.1016/j.apsoil.2007.08.005

Avitabile SC, Nimmo DG, Bennett AF, Clarke MF. Termites are resistant to the effects of fire at multiple spatial scales. PLoS ONE. 2015;10:e0140114. https://doi.org/10.1371/journal.pone.0140114

Barrios E. Soil biota, ecosystem services and land productivity. Ecol Econ. 2007;64:269-85. https://doi.org/10.1016/j.ecolecon.2007.03.004

Benites VM, Madari B, Machado PLOA. Extração e fracionamento quantitativo de substâncias húmicas do solo: um procedimento simplificado de baixo custo. Rio de Janeiro: Embrapa Solos; 2003. (Comunicado Técnico 16).

Bezerra-Gusmão MA, Barbosa JRC, Barbosa MRV, Bandeira AG, Sampaio EVSB. Are nests of Constrictotermes cyphergaster (Isoptera, Termitidae) important in the C cycle in the driest area of semiarid caatinga in northeast Brazil? Appl Soil Ecol. 2011;47:1-5. https://doi.org/10.1016/j.apsoil.2010.11.003

Bottinelli $N$, Jouquet $P$, Capowiez $Y$, Podwojewski $P$, Grimaldi $M$, Peng $X$. Why is the influence of soil macrofauna on soil structure only considered by soil ecologists? Soil Till Res. 2015;146:118-24. https://doi.org/10.1016/j.still.2014.01.007

Box GEP, Cox DR. An analysis of transformations. J R Stat Soc. 1964;26:211-52.

Cambardella CA, Elliott ET. Particulate soil organic-matter changes across a grassland cultivation sequence. Soil Sci Soc Am J. 1992;56:777-83. https://doi.org/10.2136/sssaj1992.03615995005600030017x

Canellas LP, Berner PG, Silva SG, Silva MB, Santos GA. Frações da matéria orgânica em seis solos de uma topossequência no estado do Rio de Janeiro. Pesq Agropec Bras. 2000;35:133-43. http://doi.org/10.1590/S0100-204X2000000100016

Carmo FF, Figueiredo CC, Ramos MLG, Vivaldi LJ, Araújo LG. Frações granulométricas da matéria orgânica em Latossolo sob plantio direto com gramíneas. Biosci J. 2012;28:420-31.

Cunha TJF, Madari BE, Benites VM, Canellas LP, Novotny EH, Moutta RO, Trompowsky PM, Santos GA. Fracionamento químico da matéria orgânica e características de ácidos húmicos de solos com horizonte A antrópico da Amazônia (Terra Preta). Acta Amazon. 2007;37:91-8. https://doi.org/10.1590/S0044-59672007000100010

Donagema GK, Campos DVB, Calderano SB, Teixeira WG, Viana JHM, organizadores. Manual de métodos de análise do solo. 2. ed. rev. Rio de Janeiro: Embrapa Solos; 2011.

Donovan SE, Eggleton P, Bignell DE. Gut content analysis and a new feeding group classification of termites. Ecol Entomol. 2001;26:356-66. https://doi.org/10.1046/j.1365-2311.2001.00342.x

Echezona BC, Igwe CA. Stabilities of ant nests and their adjacent soils. Int Agrophys. 2012;26:355-63. https://doi.org/10.2478/v10247-012-0050-6

Fall S, Brauman A, Chotte J-L. Comparative distribution of organic matter in particle and aggregate size fractions in the mounds of termites with different feeding habits in Senegal: Cubitermes niokoloensis and Macrotermes bellicosus. Appl Soil Ecol. 2001;17:131-40. https://doi.org/10.1016/S0929-1393(01)00125-1

Ferreira EVO, Martins V, Inda Junior AV, Giasson E, Nascimento PC. Ação dos térmitas no solo. Cienc Rural. 2011;41:804-11. https://doi.org/10.1590/S0103-84782011005000044 
Gosling CM, Cromsigt JPGM, Mpanza N, Olff $\mathrm{H}$. Effects of erosion from mounds of different termite genera on distinct functional grassland types in an African Savannah. Ecosystems. 2012;15:128-39. https://doi.org/10.1007/s10021-011-9497-8

Hausberger B, Korb J. The impact of anthropogenic disturbance on assembly patterns of termite communities. Biotropica. 2016;48:356-64. https://doi.org/10.1111/btp.12278

Holt JA, Lepage M. Termites and soil properties. In: Abe T, Bignell DE, Higashi M, editors. Termites: evolution, sociality, symbioses, ecology. Dordrecht: Kluwer Academic Publishers; 2000. p. 389-407. https://doi.org/10.1007/978-94-017-3223-9_18

Jones CG, Lawton JH, Shachak M. Positive and negative effects of organisms as physical ecosystem engineers. Ecology. 1997;78:1946-57. https://doi.org/10.1890/0012-9658(1997)078[1946:PANEO0]2.0.CO;2

Joseph GS, Seymour CL, Cumming GS, Cumming DHM, Mahlangu Z. Termite mounds as islands: woody plant assemblages relative to termitarium size and soil properties. J Veg Sci. 2013;24:702-11. https://doi.org/10.1111/j.1654-1103.2012.01489.x

Jouquet $P$, Blanchart $E$, Capowiez $Y$. Utilization of earthworms and termites for the restoration of ecosystem functioning. Appl Soil Ecol. 2014;73:34-40. https://doi.org/10.1016/j.apsoil.2013.08.004

Jouquet $\mathrm{P}$, Bottinelli N, Shanbhag RR, Bourguignon T, Traoré S, Abbasi SA. Termites: the neglected soil engineers of tropical soils. Soil Sci. 2016;181:157-65. https://doi.org/10.1097/SS.0000000000000119

Jouquet P, Dauber J, Lagerlöf J, Lavelle P, Lepage M. Soil invertebrates as ecosystem engineers: intended and accidental effects on soil and feedback loops. Appl Soil Ecol. 2006;32:153-64. https://doi.org/10.1016/j.apsoil.2005.07.004

Jouquet P, Guilleux N, Chintakunta S, Mendez M, Subramanian S, Shanbhag RR. The influence of termites on soil sheeting properties varies depending on the materials on which they feed. Eur J Soil Biol. 2015;69:74-8. https://doi.org/10.1016/j.ejsobi.2015.05.007

Jouquet $P$, Tessier $D$, Lepage $M$. The soil structural stability of termite nests: role of clays in Macrotermes bellicosus (Isoptera, Macrotermitinae) mound soils. Eur J Soil Biol. 2004;40:23-9. https://doi.org/10.1016/j.ejsobi.2004.01.006

Kaschuk G, Santos JCP, Almeida JA, Sinhorati DC, Berton-Junior JF. Termite activity in relation to natural grassland soil properties. Sci Agric. 2006;63:583-8. https://doi.org/10.1590/S0103-90162006000600013

Köppen W, Geiger R. Handbuch der klimatologie. Berlin: Verlag von Gebrüder Bornträeger; 1938. v.4.

Lavelle $\mathrm{P}$, Bignell D, Lapage M. Soil function in changing world: the role of invertebrate ecosystems engineers. Eur J Soil Biol. 1997;33:159-93.

Lavelle P, Spain A, Blouin M, Brown G, Decaëns T, Grimaldi M, Jiménez JJ, McKey D, Mathieu J, Velasquez $E$, Zangerlé $A$. Ecosystem engineers in a self-organized soil: a review of concepts and future research questions. Soil Sci. 2016;181:91-109. https://doi.org/10.1097/SS.0000000000000155

Lima SS, Alves BJR, Aquino AM, Mercante FM, Pinheiro EFM, Sant'Anna SAC, Urquiaga S, Boddey RM. Relação entre a presença de cupinzeiros e a degradação de pastagens. Pesq Agropec Bras. 2011;46:1699-706. https://doi.org/10.1590/S0100-204X2011001200016

López-Hernández D, Brossard M, Fardeau J-C, Lepage M. Effect of different termite feeding groups on $\mathrm{P}$ sorption and $\mathrm{P}$ availability in African and South American savannas. Biol Fert Soils. 2006;42:207-14. https://doi.org/10.1007/s00374-005-0017-x

Loss A, Pereira MG, Costa EM, Beutler SJ. Frações granulométricas e oxidáveis de matéria orgânica sob diferentes sistemas de uso do solo, no Paraná, Brasil. Biosci J. 2014;30:43-54.

Obi JC, Ogunkunle AO. Influence of termite infestation on the spatial variability of soil properties in the Guinea savanna region of Nigeria. Geoderma. 2009;148:357-63. https://doi.org/10.1016/j.geoderma.2008.11.003

Oliveira LBT, Santos AC, Silva Neto SP, Silva JEC, Paiva JA. Alterações físicas e químicas do solo em virtude de construções termíticas no norte de Tocantins. Eng Agricul. 2012;20:118-30.

Pennisi E. Africa's soil engineers: termites. Science. 2015;347:596-7.

https://doi.org/10.1126/science.347.6222.596 
Peres Filho O, Salvadori JR, Sanches G, Nakano O, Terán FO. Componentes do material utilizado na construção do termiteiro do cupim-de-montículo (Isoptera: Termitidae). Pesq Agropec Bras. 1990;25:167-71.

Pinheiro LBA, Pereira MG, Lima E, Correia MEF, Silva CF, Ebeling AG. Atributos edáficos e de termiteiros de cupim-de-montículo (Isoptera: Termitidae) em Pinheiral-RJ. Floresta Ambient. 2013;20:510-20. https://doi.org/10.4322/floram.2013.047

R Development Core Team. R: A language and environment for statistical computing. R Foundation for Statistical Computing, Vienna, Austria; 2015 [accessed on 12 Oct 2015]. Available at: http://www.R-project.org/

Redford KH. The termitaria of Cornitermes cumulans (Isoptera: Termitidae) and their role in determining a potential keystone species. Biotropica. 1984;16:112-19. https://doi.org/10.2307/2387842

Ronquim CC. Conceitos de fertilidade do solo e manejo adequado para as regiões tropicais. Campinas: Embrapa Monitoramento por Satélite. (Boletim de Pesquisa e Desenvolvimento, 8).

Rückamp D, Amelung W, Borma LS, Naval LP, Martius C. Carbon and nutrient leaching from termite mounds inhabited by primary and secondary termites. Appl Soil Ecol. 2009;43:159-62. https://doi.org/10.1016/j.apsoil.2009.06.012

Rückamp D, Amelung W, Theisz N, Bandeira AG, Martius C. Phosphorus forms in Brazilian termite nests and soils: relevance of feeding guild and ecosystems. Geoderma. 2010;155:269-79. https://doi.org/10.1016/j.geoderma.2009.12.010

Rückamp D, Martius C, Bornemann L, Kurzatkowski D, Naval LP, Amelung W. Soil genesis and heterogeneity of phosphorus forms and carbon below mounds inhabited by primary and secondary termites. Geoderma. 2012;170:239-50. https://doi.org/10.1016/j.geoderma.2011.10.004

Sanchez G, Peres Filho O, Salvadori JR, Nakano O. Estrutura e sistema de aeração do cupinzeiro de Cornitermes cumulans (Kollar, 1832) (Isoptera: Termitidae). Pesq Agropec Bras. $1989 ; 24: 941-3$.

Sarcinelli TS, Schaefer CEGR, Fernandes Filho El, Mafia RG, Neri AV. Soil modification by termites in a sandy-soil vegetation in the Brazilian Atlantic rain forest. J Trop Ecol. 2013;29:439-48. https://doi.org/10.1017/S0266467413000497

Sarcinelli TS, Schaefer CEGR, Lynch LS, Arato HD, Viana JHM, Albuquerque Filho MR, Gonçalves TT. Chemical, physical and micromorphological properties of termite mounds and adjacent soils along a toposequence in Zona da Mata, Minas Gerais State, Brazil. Catena. 2009;76:107-13. https://doi.org/10.1016/j.catena.2008.10.001

Silva EA, Silva CA, Silva IR, Marques JJGSM, Araujo EF, Carvalho SA, Silva SHG, Curi N. Frações de carbono em topossequências de solos sob eucalipto com diferentes históricos de uso. Rev Bras Cienc Solo. 2012;36:1167-78. https://doi.org/10.1590/S0100-06832012000400011

Swift RS. Organic matter characterization. In: Sparks DL, Page AL, Helmke PA, Loeppert RH, editors. Methods of soil analysis. Chemical methods. Wisconsin: Soil Science Society of America; 1996. Pt. 3. p. 1011-69. 